\section{Microbial Metabolism and Further Fate of Bentazon in Soil}

WOLF-RÜDIGER KNAUBER, ${ }^{\dagger}$

ARNO J. KROTZKY, $\neq A N D$

BERNHARD SCHINK*, †

Fakultät für Biologie, Universität Konstanz, Postfach 5560, D-78457 Konstanz, Germany, and Landwirtschaftliche Versuchsstation der BASF-AG, D-67117 Limburgerhof, Germany

The transformation of the herbicide bentazon in soil was investigated with radiolabeled bentazon and its derivatives 8-hydroxybentazon, 8-methoxybentazon, and $\mathrm{N}$-methylbentazon. M ineralization of bentazon was a microbial ac tivity which required the presence of oxygen and was impeded by additional carbon substrates such as powdered alfalfa (Medicago sativa) residues. The formation of bound residues of bentazon in humic substance depended on microbial activity, too, and was stimulated by the presence of oxygen; however, there was also a significant immobilization of bentazon in the absence of oxygen. A culture of the fungus Phanerochaete chrysosporium converted 8-hydroxybentazon to a dimeric derivative. The same dimer was formed by the action of laccase. This dimer and the monomeric 8-OH-bentazon acted as key metabolites in the formation of bound residues from bentazon. The further mineralization of bound bentazon residues was a slow process, with $9.3 \%$ mineralization within $141 \mathrm{~d}$.

\section{Introduction}

Our knowledge on the fate of the herbicide bentazon in soils is scarce and partly contradictory, especially with respect to the time scales of mineralization and immobilization in soil. Half-lives of bentazon in soils, based on substrate disappearance measurements, have been estimated to be in the range of 5-10 days (1-3), butstudies based on measurement of $\mathrm{CO}_{2}$ release from radiolabeled tracers reported mineralization rates of only 3-9\% in 105 days (4). Concerning the degradation mechanisms involved, photooxidative dimerization is only of minor importance in soils (5). Instead, the main transformation of bentazon in soil appears to becaused by microbial activity. Nonetheless, the biochemical pathway of bentazon degradation has not been elucidated in detail. Partial mineralization was detected in liquid laboratory growth media inoculated with fungi, and $8-\mathrm{OH}$ bentazon was identified as a major reaction product (6). The main degradation intermediatein soil was assumed to be2-amino$\mathrm{N}$-isopropyl benzamide (7) which was detected only at trace concentrations and would easily be hydrolyzed to anthranilate plus isopropylamine. A recent review on the environmental behavior of bentazon confirms that our knowledge on this matter is still fragmentary (8).

A major problem in degradation of xenobiotics in soil is their tendency to attach to humic soil constituents and to

* Correspondingauthor phone: +49-7531-882140; fax: +49-753188 2966; e-mail: Bernhard.Schink@uni-konstanz.de.

† Universität Konstanz.

‡ Landwirtschaftliche Versuchsstation der BASF-AG.<smiles>[R7]c1cccc2c1N([R20])[13CH2]N(C(C)C)C2=O</smiles>

FIGURE 1. Chemical structures of bentazon and its derivatives used in the present study. The asterisk indicates the part labeled for tracer experiments. $\mathbf{R}_{1}=H, R_{2}=H$ : bentazon; $R_{1}=O H, R_{2}=H$ : 8-hydroxybentazon; $\mathbf{R}_{1}=\mathrm{OCH}_{3}, \mathbf{R}_{\mathbf{2}}=\mathrm{H}$ : 8-methoxybentazon; $\mathbf{R}_{1}=$ $\mathrm{H}, \mathrm{R}_{2}=\mathrm{CH}_{3}: \mathrm{N}$-methylbentazon.

form bound residues which are comparably stable toward microbial attack $(9,10)$. Also bentazon appears to attach to the soil humic substance as indicated by a negative correlation observed between carbon content of soils and leaching of bentazon into lower soil and ground water layers (11). A recent study with bentazon and aromatic cosubstrates in the presence of laccase or peroxidase enzymes showed that bentazon and its derivatives were transformed by these enzymes, preferentially under acidic conditions, and that especially the $6-\mathrm{OH}$ and $8-\mathrm{OH}$ derivatives were most reactive (12).

The present study was initiated in order to explain the discrepancy between the reported rates of bentazon disappearance in soil and those of bentazon mineralization. A detailed analysis of theinfluence of the organic matter content of soil, of oxygen availability, of fungal and bacterial activity, and of possible effects by free enzymes on bentazon transformation was performed to provide a better understanding of bentazon metabolism in soil, including the formation and degradation of intermediates and their interaction with the soil humic substance.

\section{Experimental Section}

Radiochemicals. U- ${ }^{14} \mathrm{C}$-phenyl labeled bentazon (3-isopropyl-1H-2,1,3-benzothiadiazin-4(3H)-one-2,2-dioxide, 1616 $\left.\mathrm{kBq} \cdot \mathrm{mg}^{-1}\right)$ and its metabolites $\left(\mathrm{U}-{ }^{14} \mathrm{C}\right.$-phenyl) $\mathrm{N}$-methylbentazon $\left(1527 \mathrm{kBq} \cdot \mathrm{mg}^{-1}\right)$ and $\left(\mathrm{U}-{ }^{14} \mathrm{C}\right.$-phenyl) 8-OH-bentazon (1177 $\mathrm{kBq} \cdot \mathrm{mg}^{-1}$ ) were synthesized by BASF AG, Ludwigshafen, Germany (structures see Figure 1 ). U- ${ }^{14} \mathrm{C}$ phenyl-labeled anthranilic acid (2-amino benzoic acid; Amersham/Buchler GmbH, Braunschweig, Germany; 3086 $\mathrm{kBq} \cdot \mathrm{mg}^{-1}$ ) was used in transformation experiments for comparison.

A sample of $\mathrm{N}^{14} \mathrm{C}$-methyl labeled $\mathrm{N}$-methylbentazon $\left(8032 \mathrm{kBq} \cdot \mathrm{mg}^{-1}\right)$ was synthesized by reaction of nonlabeled bentazon with ${ }^{14} \mathrm{C}$-methyl iodide in $100 \mathrm{~mL}$ of dichloromethane as solvent. Fifty milliliters of $0.1 \mathrm{M}$ tetrabutylammonium hydrogensulfatein $0.5 \mathrm{M} \mathrm{NaOH}$ was added, and the solution was shaken at $80 \mathrm{rpm}$ for $12 \mathrm{~h}$. The product was purified and checked for purity by preparativeand analytical thin-layer chromatography. A sample of ${ }^{14} \mathrm{C}$-8-methoxy-Nmethylbentazon was synthesized by reacting $10 \mathrm{mg}$ of nonlabeled 8-OH-bentazon in $10 \mathrm{~mL}$ of methanol with ${ }^{14} \mathrm{C}$ diazomethanewhich was added continuously under shaking until a yellow color remained in the solution for more than $2 \mathrm{~h}$. Excess diazomethanewas destroyed by addition of formic acid, nonreacted 8-OH-bentazon was removed by phase separation after addition of $0.1 \mathrm{M} \mathrm{NaOH}$, and the product was purified and checked for purity by preparative and analytical thin-layer chromatography [silica gel plates 60 F-254, $200 \times 200 \times 0.25$ mm (Merck, Darmstadt, Germany), separation with $65 \%$ cyclohexane, 35\% 2-propanol, 0.3\% glacial acetic acid for $90 \mathrm{~min}$, scanning either under UV light 
(254 $\mathrm{nm}$ ) or by radioactivity scanning (LKB 2842, Berthold, Wildbad, Germany)].

Labeled humic substance was synthesized from ${ }^{14} \mathrm{C}$ anthranilic acid following the procedureof $\mathrm{M}$ artin and Haider (13). U- ${ }^{14} \mathrm{C}$ anthranilic acid $(6.05 \mathrm{mg})$ dissolved in $0.25 \mathrm{~mL}$ of methanol was added to a $0.9 \%$ (w/v) $\mathrm{KH}_{2} \mathrm{PO}_{4}$ solution, $\mathrm{pH}$ 5.0, containing 4500 units of peroxidase(Sigma, Deisenhofen, Germany). One gram of humic substance from soil and $2 \mathrm{~mL}$ of $\mathrm{H}_{2} \mathrm{O}_{2} 30 \%(\mathrm{v} / \mathrm{v})$ were added, and the mixture was stirred under air at $25^{\circ} \mathrm{C}$ for $12 \mathrm{~h}$. The enzyme was precipitated with acetone under sonication and removed by centrifugation (15 min at $20000 \mathrm{~g}$ ). The product was fractionated by thinlayer chromatography and binding on Amberlite XAD-8 (Serva, Heidelberg; binding at $\mathrm{pH} 2.0$, release at $\mathrm{pH}$ 8.0) to remove nonbound anthranilic acid.

Soil Incubation Experiments. Experiments were carried out with $A_{p}$ soil samples taken from a barley field to which bentazon had been applied for 5 years. Air-dried soil was sieved $(<2 \mathrm{~mm})$ and stored at $4{ }^{\circ} \mathrm{C}$. It was classified as a sandy clay loam (USDA scheme) of the Alfisol type with a maximum waterholding capacity of $36 \mathrm{~g}$ of $\mathrm{H}_{2} \mathrm{O} \cdot 100 \mathrm{~g}$ of dry soil $^{-1}$. The $\mathrm{pH}$ was 7.5 , the total carbon content $1.2 \%(\mathrm{w} / \mathrm{w})$, and the total nitrogen content $0.13 \%(\mathrm{w} / \mathrm{w})(\mathrm{C} / \mathrm{N}$-ratio 9.2). The microbial biomass was measured indirectly with a Sapromat (Type B 12, Voith, Germany) as oxygen consumption after glucose addition (14). It was $36.9 \mathrm{mg}$ of $\mathrm{C} \cdot 100 \mathrm{~g}$ of dry soil $^{-1}$. For incubation experiments, $100 \mathrm{~g}$ of soil material adjusted to $60 \%$ maximum water holding capacity was used per incubation flask, and five replicate flasks were run per experiment. To check for possible effects of the soil organic matter content, alfalfa (M edi cago sativa) plant residues were added as a dry powder to the soil as indicated. ${ }^{14} \mathrm{C}$-labeled tracer compounds ( $0.3 \mathrm{mg}$ per $100 \mathrm{~g}$ of soil), actidione (1.6 g per $100 \mathrm{~g}$ of soil), and streptomycin ( $1.0 \mathrm{~g}$ per $100 \mathrm{~g}$ of soil) were dissolved in aliquots of $3 \mathrm{~mL}$ of methanol and mixed into the soil; the methanol was removed afterward by evaporation at $20^{\circ} \mathrm{C}$ under a continuous air stream. Actidione and streptomycin served as inhibitors of possible fungal or bacterial activities. Nitrate (5, 10, $20 \mathrm{mg} \mathrm{N}$ per $100 \mathrm{~g}$ of soil) was added as an al ternative electron acceptor in someanoxic incubation experiments. It was supplied as an aqueous solution that was adjusted to give the same final humidity as with the other soil samples. For sterile control assays, soil was sterilized by three cycles of autoclaving for $1 \mathrm{~h}$ each on 3 subsequent days. The flasks were incubated in a special airtight steel tube (Memmert, Germany) at $20{ }^{\circ} \mathrm{C}$ for a minimum of 21 days in the dark. Anoxic incubation conditions were accomplished by gassing the steel tubes with $\mathrm{N}_{2}$ for at least $5 \mathrm{~min}$; flushing with air restored oxic conditions.

Freundlich adsorption isothermswere determined under sterile conditions with artificial clay-humic complexes synthesized according to ref 15 by mixing $1 \mathrm{~g}$ of freeze-dried humic substance with $10 \mathrm{~g}$ of amino silicagel (Nucleosil 5 $\mathrm{NH}_{2}$, Macherey and Nagel, Düren, Germany) in $100 \mathrm{~mL}$ of double distilled $\mathrm{H}_{2} \mathrm{O}$. This material was washed with $20 \mathrm{~mL}$ of $0.9 \%(w / v) \mathrm{KH}_{2} \mathrm{PO}_{4}, 20 \mathrm{~mL}$ of $\mathrm{H}_{2} \mathrm{O}$, and $20 \mathrm{~mL}$ of methanol with intermediate centrifugation steps (12000g, $10 \mathrm{~min}$ ) to remove nonbound humic material. For tests, $100 \mu \mathrm{g}$ of $\mathrm{U}-{ }^{14} \mathrm{C}-$ phenylbentazon, $\mathrm{U}-{ }^{14} \mathrm{C}$-phenyl-8-OH-bentazon, or $\mathrm{N}-{ }^{14} \mathrm{C}$ methylbentazon was added to $250 \mathrm{mg}$ of clay-humic complexes in $6 \mathrm{~mL}$ of sterile distilled $\mathrm{H}_{2} \mathrm{O}$. After stirring for $72 \mathrm{~h}$, the complexes were centrifuged again, and $250 \mathrm{~mL}$ aliquots of supernatant were counted by liquid scintillation. Acontrol experiment was run with aminosilicate alone.

Binding of bentazon and itsderivativesto artificial clayhumic complexes by the action of enzymes was studied under similar conditions. An aliquot of $15 \mathrm{mg}$ of labeled bentazon, 8-OH-bentazon, or a dimeric 8-OH-bentazon was incubated with $450 \mathrm{U}$ of laccase, peroxidase, or tyrosinase (Sigma, Deisenhofen; definitions of enzyme units according to the manufacturer's catalog) in $10 \mathrm{~mL}$ of $0.1 \mathrm{M} \mathrm{KH}_{2} \mathrm{PO}_{4} /$ $\mathrm{Na}_{2} \mathrm{HPO}_{4}$ buffer, $\mathrm{pH} 7.2$, under air with stirring $\left(80 \cdot \mathrm{min}^{-1}\right)$ for $24 \mathrm{~h}$ at $22^{\circ} \mathrm{C}$. The assay with peroxidase contained in addition $45 \mathrm{~mL}$ of $\mathrm{H}_{2} \mathrm{O}_{2}(30 \% \mathrm{v} / \mathrm{v})$. The reactions werestopped by precipitation of the enzymes with acetone under sonication and subsequent centrifugation (15 min at $20000 \mathrm{~g}$ ).

Enzymatic Dimerization of 8-OH-Bentazon. Two hundred micrograms of nonlabeled 8-OH-bentazon dissolved in $10 \mathrm{~mL}$ of $0.1 \mathrm{M} \mathrm{KH}_{2} \mathrm{PO}_{4} / \mathrm{Na}_{2} \mathrm{HPO}_{4}$ buffer, $\mathrm{pH} 6.5$, was reacted with laccase ( $450 \mathrm{U} \cdot \mathrm{mL}^{-1}$; Sigma, Deisenhofen) for $24 \mathrm{~h}$ at $25^{\circ} \mathrm{C}$. The deep-red product was purified by precipitation with $4 \mathrm{M} \mathrm{HCl}$ and subsequent dialysis against distilled $\mathrm{H}_{2} \mathrm{O}$. It was characterized by mass spectrometry on an HPLC-MS system (PE-SCIEX API III; Perkin-Elmer, Überlingen, Germany).

Incubation Experiments with a Pure Fungal Culture. The white-rot fungus Phanerochaete chrysosporium (DSM 1556) was obtained from the Deutsche Sammlung für Mikroorganismen und Zellkulturen $\mathrm{GmbH}$, Braunschweig, Germany, and was cultivated in mineral medium (16). For incubation experiments, about $200 \mathrm{mg}$ of washed wet mycelium was mixed with $100 \mathrm{~g}$ of natural or sterilized soil, and incubations with bentazon were run analogous to those with natural soil as described above.

Analyses. The released radioactive compounds were trapped in $25 \mathrm{~mL}$ of ethylene glycol/methanol (1:1) and 25 $\mathrm{mL}$ of $1 \mathrm{~N} \mathrm{H}_{2} \mathrm{SO}_{4} ;{ }^{14} \mathrm{CO}_{2}$ was absorbed in a further flask with $25 \mathrm{~mL}$ of $1 \mathrm{M} \mathrm{NaOH}$. After incubation, the soil material was stored at $-20^{\circ} \mathrm{C}$ until further extraction. Parent compounds and metabolites were extracted twice with a 10 -fold volume of methanol. Aliquots of these extracts were transferred into $20 \mathrm{~mL}$ of scintillation cocktail (Ultima Gold XR, Packard, Meridan, CT) and counted in a liquid scintillation counter (1219 RackBeta, LKB, Wallac Oy, Turkku/Finland). Extracts were also separated by thin layer chromatography (silica gel plates 60F-254, 20·20 0.25 cm, Merck, Darmstadt, Germany; solvent: $65 \%$ (v/v) cyclohexane/35\% (v/v) 2-propanol/ 0.3\% ( $v / v)$ acetic acid) for $90 \mathrm{~min}$. The following $R_{f}$ values were obtained: bentazon 0.41 , 8-OH-bentazon 0.26, 8-methoxybentazon $0.34, \mathrm{~N}$-methylbentazon 0.62 .

Soil humic material was extracted under $\mathrm{N}_{2}$ atmosphere with $0.1 \mathrm{M}$ sodium pyrophosphate and $0.5 \mathrm{M} \mathrm{NaOH}$, according to refs 17 and 18. Extracts were centrifuged (10 000g, $15 \mathrm{~min}$ ) and filtered through a folded filter. Radioactivity in this alkaline extract was quantified by scintillation counting. Radioactivity bound to fulvic acids was separated after adjustment to $\mathrm{pH} 1.0$ with $4 \mathrm{~N} \mathrm{HCl}$, freezing, thawing, and centrifugation (10000g, $15 \mathrm{~min}$ ). Radioactivity in the supernatant was counted again, and the differences in radioactivity were attributed to labeled compounds in humic acids. The amount of radioactivity bound to humin and the inorganic soil fraction was calculated by subtraction of the total amount of alkali-extracted radioactivity from the data gained by combustion of soil material after methanol extraction.

For determination of soil-bound radioactivity, $0.2 \mathrm{~g}$ of samples of methanol-extracted soils were incinerated in an analytic oxidizer (Ox300, Zinsser, Frankfurt/Main, Germany), and ${ }^{14} \mathrm{CO}_{2}$ was absorbed in Oxosol ${ }^{14} \mathrm{C}$ (National Diagnostics).

Microorganismsin soil werecounted in extracts obtained from $20 \mathrm{~g}$ of dry soil with $180 \mathrm{~mL}$ of $0.18 \%$ (w/ v) aqueous sodium pyrophosphate solution. Aliquots were used for counting of colony-forming units (CFU) by plating on nutrient broth agar (incubation for $48 \mathrm{~h}$ at $25^{\circ} \mathrm{C}$ ) or by the mostprobable-number method with liquid nutrient broth medium (incubation for 3 weeks at $25^{\circ} \mathrm{C}$ ). To check for possible side effects of cosubstrates, the carbon content of the soils was increased in parallel experiments by addition of a powder of Medicago sativa. 
TABLE 1: Conversion of Bentazon (3 mg per $\mathrm{kg}$ of soil) to $\mathrm{CO}_{2}$, Counts of Heterotrophic Bacteria, and Specific Bacterial Bentazon-Degrading Activity in Unamended Soil and in Soil Amended with Plant Material (Medicago sativa Powder) ${ }^{a}$

\begin{tabular}{|c|c|c|c|}
\hline & unamended & $\begin{array}{c}+1 \% \\
\text { M. sativa }\end{array}$ & $\begin{array}{c}+3 \% \\
\text { M. sativa }\end{array}$ \\
\hline $\begin{array}{l}\mu \mathrm{g}{ }^{14} \mathrm{C} \text {-bentazon } \\
\text { mineralized } \\
\times \text { kg dry soil }{ }^{-1}\end{array}$ & $379 \pm 44$ & $315 \pm 36$ & $268 \pm 31$ \\
\hline$=\%$ of total label applied & 12.3 & 10.3 & \\
\hline CFU $\cdot g$ dry soil ${ }^{-1}$ & $\begin{array}{c}6.6 \pm 2.4 \\
\cdot 10^{7}\end{array}$ & $\begin{array}{l}2.04 \pm 0.8 \\
\cdot 10^{8}\end{array}$ & $\begin{array}{c}8.6 \pm 2.9 \\
\cdot 10^{8}\end{array}$ \\
\hline $\begin{array}{l}\mu \mathrm{g}^{14} \mathrm{CO}_{2} \text { released } \times \mathrm{kg} \\
\text { dry soil }^{-1}\end{array}$ & 63.6 & 56.6 & 47.3 \\
\hline $\mathrm{fg}^{14} \mathrm{CO}_{2}$ released $\times \mathrm{CFU}^{-1}$ & 0.96 & 0.28 & 0.055 \\
\hline \multicolumn{4}{|c|}{$\begin{array}{l}{ }^{a} \text { Assays were performed after } 35 \text { days of incubation. The }{ }^{14} \mathrm{CO}_{2} \\
\text { released was measured for every set of experiments (five replicas in } \\
\text { each set). Bacterial counts were determined in three separate runs each. } \\
\mathrm{CFU}=\text { colony-forming units, } \mathrm{fg}=10^{-15} \mathrm{~g} \text {. }\end{array}$} \\
\hline
\end{tabular}

\section{Results and Discussion}

Influence of Organic Cosubstrates on Bentazon Mineralization. Previous experiments had indicated that bentazon metabolism in different soils was influenced by thesoil carbon content. Therefore, we studied bentazon degradation in the presenceand absence of various amounts of alfalfa (Medicago sativa) powder added to the soil. Alfalfa powder was chosen because of its high content of easily available carbon and nitrogen ( $\mathrm{C} / \mathrm{N}$-ratio 13$)$ to prevent nitrogen limitation of microbial growth. In four parallel runs, ${ }^{14} \mathrm{CO}_{2}$ was released from labeled bentazon at a constant rate after an initial adaptation period of 7-10 days (resultsnotshown). Asshown in Table 1, the total amount of ${ }^{14} \mathrm{CO}_{2}$ released after 35 days decreased with increasing total carbon content in the soil although the number of microorganisms increased, as assayed by plate counts on complex medium. This effect became even more pronounced when the amounts of mineralized bentazon per colony-forming unit were calculated (Table 1). In the presence of 3\% (w/w) alfalfa powder per kg of soil, the bentazon mineralization activity per colonyforming unit was only $5 \%$ of that in unamended soil.

Obviously, bentazon mineralization was impeded by the presence of easily degradablecarbon. This effect may bedue in part to sorption of bentazon to the added organic material. Nonetheless, bentazon degradation appears not to be a strictly cometabolic process that would be expected to be enhanced by addition of carbon cosubstrates as described for several other xenobiotic compounds $(19,20)$. On the other hand, the degradative activity did not adapt to bentazon utilization since soils treated with bentazon for several years showed only slightly greater mineralization activities than unamended soils (unpublished data, BASF AG). A different study reported that bentazon-treated soils develop a higher bentazon degradation capacity than untreated soils (21), indicating that bentazon-degrading microorganisms may be enriched upon long-term soil treatment. Efforts in our laboratory to enrich for bentazon-degrading microorganisms in liquid cultures were unsuccessful, indicating that at least one step in this process was catalyzed by an organism which did not profit sufficiently from this activity to allow specific cell multiplication under theenrichment conditions applied.

Influence of Microbial Activities and Oxygen on Bentazon Mineralization and on Formation of Bound Residues. Release of ${ }^{14} \mathrm{CO}_{2}$ from $\mathrm{U}-{ }^{14} \mathrm{C}$-phenyl labeled bentazon was due to microbial activity. The highest release of ${ }^{14} \mathrm{CO}_{2}$ was found with untreated soil (Figure 2). In sterilized soil, no mineralization could be detected. The influence of bacteria or fungi on bentazon mineralization was checked in experiments with soil amended with streptomycin to inhibit

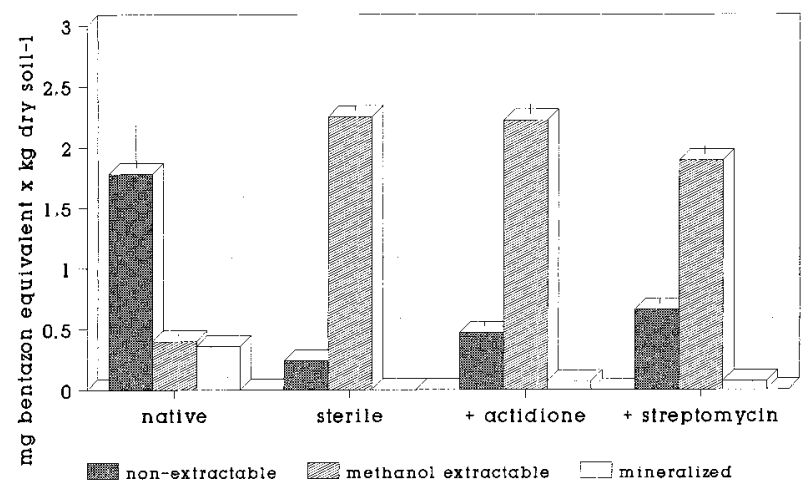

FIGURE 2. Recovery of radioactive derivatives from ring-labeled bentazon after incubation in soil for $28 \mathrm{~d}$ under various conditions as indic ated. Three milligrams of labeled bentazon w as applied per $\mathrm{kg}$ of soil.

bacteria or with actidione to inhibit fungi. In both cases, the release of ${ }^{14} \mathrm{CO}_{2}$ was only $20 \%$ of that of untreated soil (Figure 2) indicating that both bacteria and fungi contributed to bentazon mineralization.

M ost of the added labeled bentazon was not extractable with methanol after incubation with untreated soil (Figure 2). Also this transformation of bentazon to a bound (nonextractable) residue was mainly due to microbial activity. A minor part of the added label was found to be bound also in sterile soil, perhaps as a consequence of abiotic partial oxidation by metal oxides $(10,22)$. Nonetheless, the majority of the label was bound by microbial activity in the nonsterile soil, and both prokaryotes and eukaryotes contributed to this binding activity. Fungi appeared to be involved to a greater extent than bacteria: in soils treated with actidione, $10.7 \%$ less radioactivity was bound to soil material, compared to soilstreated with streptomycin; however, thesmall number of experiments reported here does not allow a generalization of these findings at present. Anderson and Domsch (23) regarded fungi as the most important microorganismsactive in metabolism of xenobiotics in soil.

Significant release of ${ }^{14} \mathrm{CO}_{2}$ from $\mathrm{U}^{14} \mathrm{C}$-phenyl labeled bentazon was observed only in the presence of oxygen. Under anoxic conditions, the mineralization activity was less than $5 \%$ of the aerobic activity (Figure 3a). Addition of nitrate as an alternative electron acceptor to anoxic incubation experiments did not increase the ${ }^{14} \mathrm{CO}_{2}$ release. If the atmosphere was changed from anoxic to oxic and back to anoxic again, ${ }^{14} \mathrm{CO}_{2}$ release was observed nearly exclusively during the periods of oxygen access (Figure 3a).

Also the formation of bound residues was stimulated by oxygen (Figure $3 b)$. Even small amounts of oxygen $(0.05 \%$ ( $v / v) \mathrm{O}_{2}$ ) allowed formation of bound residues to nearly full extent; higher oxygen contents did not increase the rate of formation of bound residues further (results not shown). Anoxic conditions did not prevent further formation of bound residues after an initial oxic incubation, indicating that a reactive derivative had been formed that could bind also under anoxic conditions.

Formation of Bound Residues from Bentazon Derivatives. To characterize the type of binding to the humic substance into more depth, ${ }^{14} \mathrm{C}$-labeled bentazon and its derivatives 8- $\mathrm{OH}$-bentazon, $\mathrm{N}$-methylbentazon, and anthranilate were incubated with soil in experiments similar to those described above. 8-OH-bentazon was used because it had been detected as a metabolite in cultures of bentazondegrading fungi (6). N-methylbentazon has been detected in soil amended with bentazon ((23) also unpublished results, BASF AG); methylation of bentazon and subsequent demethylation have been reported to be unspecific side activities of several microorganisms (24), and such a meth- 

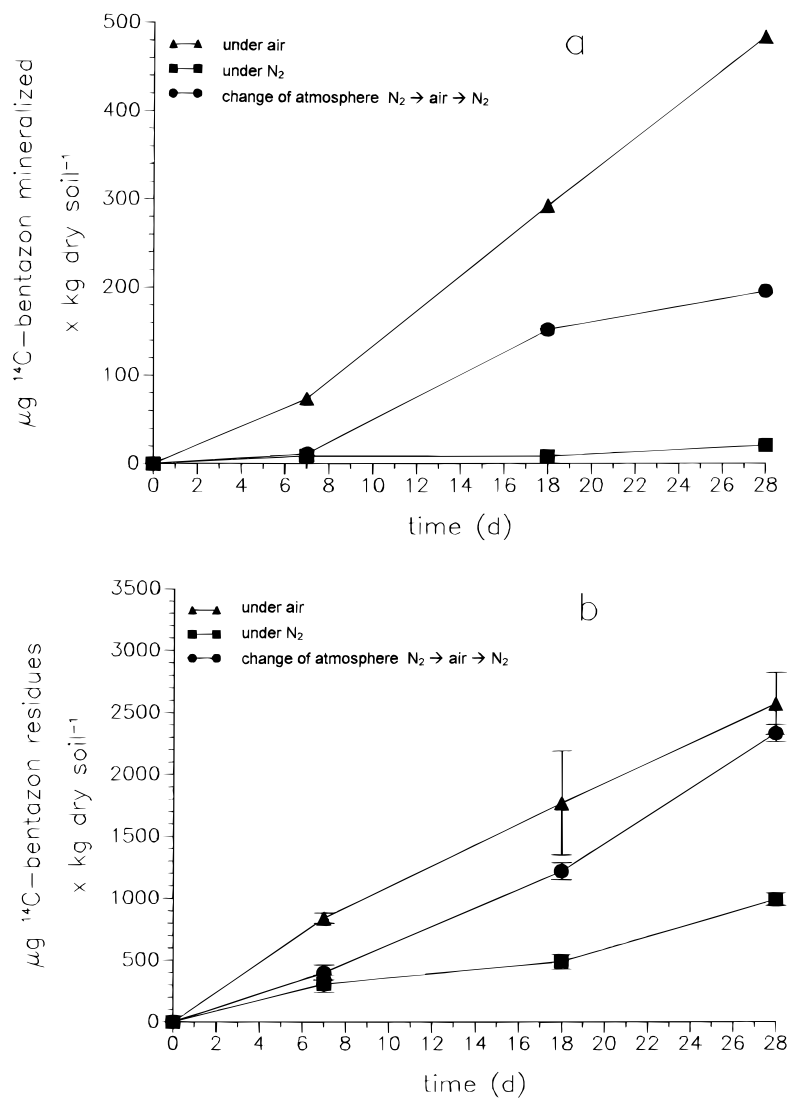

FIGURE 3. Fate of radioactivity of ring-labeled bentazon ( $3 \mathrm{mg}$ per $\mathrm{kg}$ of soil) in soil during inc ubation under changing gas atmospheres (anoxic/oxic/anoxic): (a) release of ${ }^{14} \mathrm{CO}_{2}$ and (b) formation of bound residues. ${ }^{14} \mathrm{CO}_{2}$ released $w$ as measured for every separate set of experiments (five replicas in each set).

ylation-demethylation cycle was described also for the fungicide Chloroneb (25). Anthranilate was applied as a putative intermediate in bentazon mineralization and as an important precursor of humic substanceformation. Of these compounds, 8-OH-bentazon was bound most efficiently to humic substance. This binding was equally effective in native and in sterile soil, indicating that it was a purely chemical process (Figure 4a). Also anthranilate exhibited a high tendency to bind to humic material, independent of microbial activity. Bentazon and $\mathrm{N}$-methylbentazon were bound to equal but far lower extent than the hydroxy compound. Both substances formed morethan twiceas much bound residues in native soils as under sterile conditions.

Whereas radioactive 8-OH-bentazon or anthranilate after incubation was associated with humic acids or humin, most of the bound bentazon or $\mathrm{N}$-methylbentazon was found in the fulvic acid fraction (Figure 4b). If it is true that humic substances age during humification from fulvic acids via humic acids to humins, our observations indicate that 8-OHbentazon and anthranilate are transformed faster into the morestablefraction of soil humics, perhapsthrough a further intermediate (see below), than bentazon or $\mathrm{N}$-methylbentazon.

The observed binding of bentazon to humic substances was not only physicochemical adsorption. Freundlich adsorption isothermswere determined with artificial clay-humic complexes $(\mathrm{k}=0.058$ for bentazon, 0.13 for $8-\mathrm{OH}$-bentazon, and 0.022 for $\mathrm{N}$-methylbentazon) and were found to be substantially lower than the lowest such value reported in the literature (adsorption of benzene to a static clay-humic phase, $k=0.23$ (15)). Thus, adsorption might play only a minor role in binding of bentazon and its derivatives to clayhumic complexes.
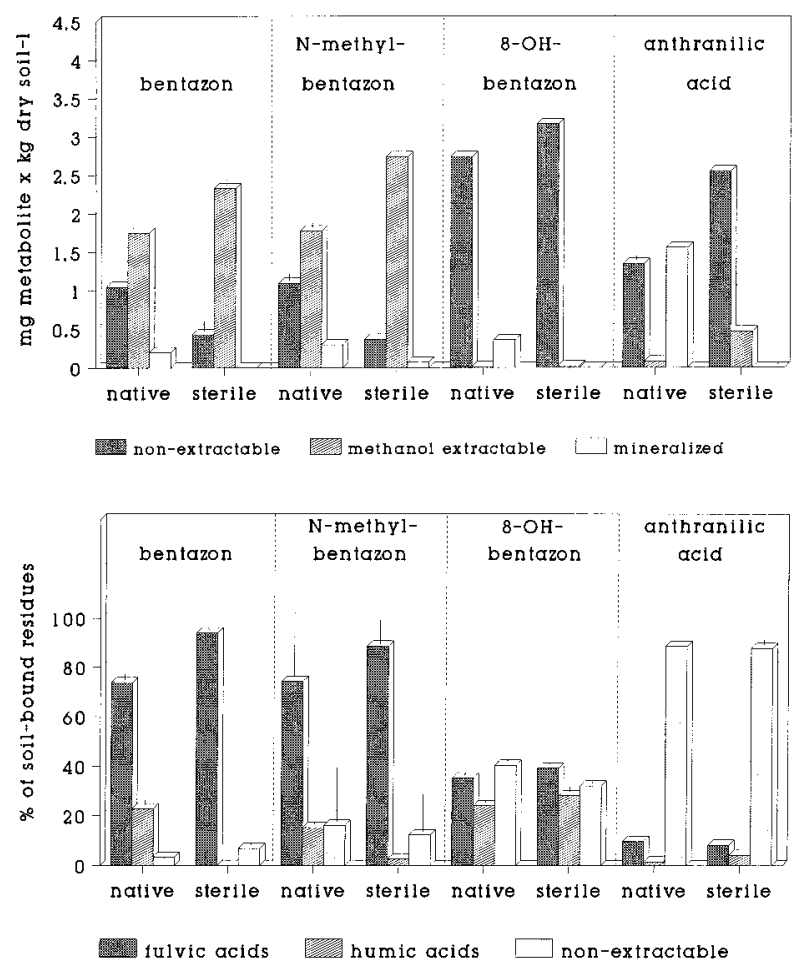

FIGURE 4. Fate of $\mathrm{N}$-methylbentazon, 8-OH-bentazon, bentazon, and anthranilate (3 $\mathrm{mg}$ per $\mathrm{kg}$ of soil each) during incubation in soil for $32 \mathrm{~d}$. (a) M ineralization and formation of bound residues. (b) Rec overy of radioactivity in different fractions of humic material.

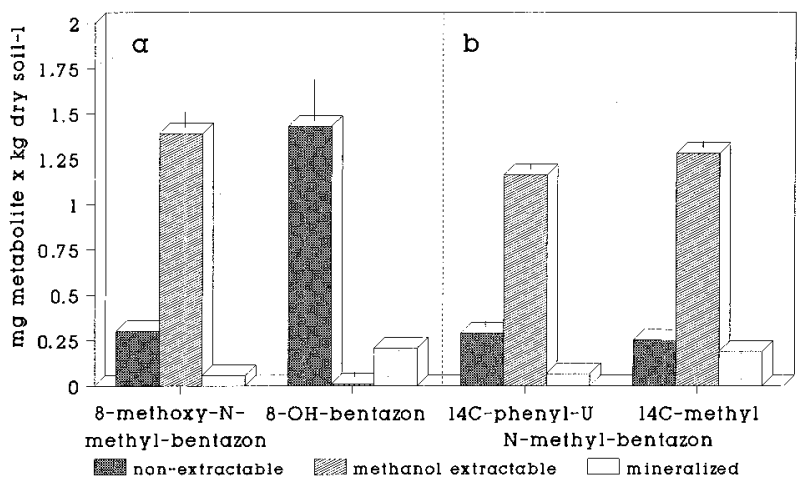

FIGURE 5. Formation of bound residues from ring-labeled 8-0Hbentazon, 8-methoxy- $\mathrm{N}$-methylbentazon, and $\mathrm{N}-{ }^{14} \mathrm{C}$-methylbentazon in comparison to $\mathrm{N}$-methyl ${ }^{14} \mathrm{C}$-phenylbentazon during incubation in soil for $28 \mathrm{~d} .1 .75 \mathrm{mg}$ of labeled compound was applied per $\mathbf{k g}$ of soil.

To investigate the function of the hydroxyl group in binding of 8-OH-bentazon to humic material, we masked this group by methylation. The methylated derivative was bound to a far lower extent than the parent compound (Figure 5a). O-methylation also changed thebinding pattern of 8-OHbentazon in the various fractions of humic substances: whereas $56 \%$ of $8-\mathrm{OH}$-bentazon bound to the humic acid fraction, $98 \%$ of the O-methylated bentazon bound to the fulvic acid fraction (results not shown). N-methylation, on the other hand, did not prevent the formation of bound residues. Labeled $\mathrm{N}$-methyl bentazon was bound to the same extent as labeled bentazon. The label of $\mathrm{N}-{ }^{14} \mathrm{C}$-methylbentazon was bound to humic material to the sameextent as did the radioactivity of the phenyl-labeled tracer although the methyl carbon was mineralized three times faster than the phenyl carbon (Figure 5b). Thus, also the methyl carbon was incorporated into the humic substance, but this transforma- 
TABLE 2: Binding of Bentazon, 8-OH-Bentazon, and Its Dimeric Derivative to Artificial Clay-Humic Complexes and Aminosilicate by Reaction with Laccase, Peroxidase, and Tyrosinase ${ }^{\mathrm{a}}$

\begin{tabular}{|c|c|c|c|c|}
\hline enzyme & $\begin{array}{c}\text { metabolite } \\
\text { provided } \\
\mu \mathrm{g} \cdot \mathrm{mL}^{-1}\end{array}$ & $\begin{array}{c}\text { metabolite } \\
\text { dissolved } \\
\text { after incubation } \\
\mu \mathrm{g} \cdot \mathrm{mL}^{-1}\end{array}$ & $\begin{array}{c}\text { metabolite } \\
\text { bound } \\
\mu \mathrm{g} \cdot \mathrm{mL}^{-1}\end{array}$ & $\begin{array}{l}\text { part boun } \\
\text { of total } \\
\text { metabolit } \\
\text { provided }\end{array}$ \\
\hline \multicolumn{5}{|c|}{ Bentazon Plus Aminosilicate ${ }^{b}$} \\
\hline ccase & 34.2 & 33.9 & 0.3 & 0.9 \\
\hline eroxidase & 32.0 & 35.2 & 0 & \\
\hline sinase & 33.3 & 35.6 & & \\
\hline \multicolumn{5}{|c|}{ Bentazon Plus Artificial Clay-Humic Complex ${ }^{b}$} \\
\hline laccase & 33.8 & 35.8 & 0 & 0 \\
\hline peroxidase & 33.5 & 34.9 & 0 & 0 \\
\hline tyrosinase & 31.7 & 34.5 & 0 & 0 \\
\hline \multicolumn{5}{|c|}{ 8-OH-Bentazon Plus Aminosilicate ${ }^{b}$} \\
\hline laccase & 20.9 & 24.6 & 0 & 0 \\
\hline peroxidase & 25.5 & 26.6 & 0 & 0 \\
\hline tyrosinase & 24.7 & 26.9 & 0 & 0 \\
\hline \multicolumn{5}{|c|}{ 8-OH-Bentazon Plus Artificial Clay-Humic Complex $b$} \\
\hline laccase & 24.6 & 6.5 & 18.1 & 73.6 \\
\hline eroxidase & 25.7 & 26.3 & $\Omega$ & 0 \\
\hline tyrosinase & 25.4 & 10.7 & 14.8 & 58.1 \\
\hline \multicolumn{5}{|c|}{ 8-OH-Bentazon Dimer Plus Clay-Humic Complex } \\
\hline & $4.6 \pm$ & $1.9 \pm 0.01$ & 2.7 & 58.7 \\
\hline
\end{tabular}

${ }^{a}$ Reaction mixtures were incubated for $72 \mathrm{~h}$ at $25^{\circ} \mathrm{C}$ as detailed in the Experimental Section. Numbers give means of the results of two independent experiments which differed by $12 \%$ at maximum. ${ }^{b}$ Treatment.

tion proceeded at a different rate and probably by a reaction process different from that of the phenyl carbon.

Oxidative Dimerization of 8-OH-Bentazon. Although 8-OH-bentazon had been detected earlier as an intermediate in cultures of bentazon-degrading fungi (6) we could never detect this metabolite in soils. Instead, we found a polar metabolite in methanol extracts of soil, especially in those soil samples that had been inoculated with the fungus Phanerochaetechrysosporium. This compound accumulated to $3-4 \%(w / w)$ of the added parent compound. The same metabolite could be produced from 8-OH bentazon enzymatically by treatment with laccase. The deep-red derivative was purified. Mass spectrometry after HPLC separation (not shown) revealed that two molecules of 8-OH-bentazon were linked to each other by an ether linkage, most probably between the carbon atoms 8 and 5 . This structure was confirmed by mass spectrometry with secondary fragmentation and subsequent mass spectrometry (MS-MS coupling; results not shown). Tri- or tetramers were not detected; however, these could have been destroyed in the fragmentation process.

Laccase and tyrosinase both catalyzed a covalent binding of 8-OH-bentazon to artificial clay-humic complexes. Laccase bound $73.6 \%$ and tyrosinase $58.1 \%$ of the added parent compound; no binding was found with peroxidase(Table2). Peroxidase and tyrosinase did not immobilize bentazon at all, and the momomeric 8-OH-bentazon was bound specifically to clay-humic complexes (58-74\%), not to aminosilicate. The dimeric 8-OH-bentazon derivative bound to the clay-humic complexes and also to aminosilicate, even without participation of enzymes.

Addition of Phanerochaete chrysosporium to native soil caused significantly faster binding of bentazon to humic substances $(0.91 \pm 0.03 \mathrm{mg}$ per $\mathrm{kg}$ of soil) than did noninoculated soil with its autochronous microorganisms $(0.65 \pm 0.02 \mathrm{mg}$ per $\mathrm{kg}$ of soil). Obviously, the high reactivity of 8-OH-bentazon precluded detection of this intermediate

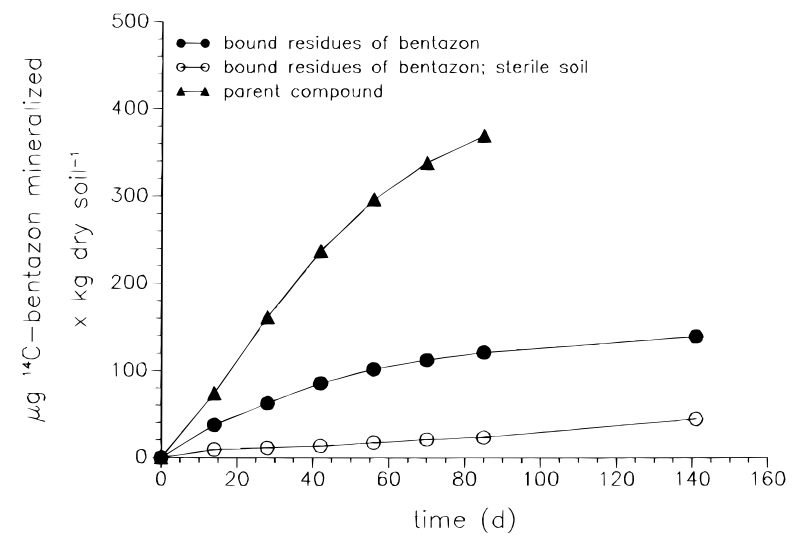

FIGURE 6. Release of ${ }^{14} \mathrm{CO}_{2}$ from ${ }^{(14} \mathrm{C}$-phenyl)bentazon and from bound residues previously formed from $\left({ }^{14} \mathrm{C}\right.$-phenyl)bentazon during incubation in soil for $141 \mathrm{~d}$. The ${ }^{14} \mathrm{CO}_{2}$ released was measured for every separate set of experiments (three replicas in each set).

in soil because it was immediately dimerized and/ or bound to the humic substance.

We conclude that the formation of bound residues was due to microbial hydroxylation of bentazon to $8-\mathrm{OH}$ bentazon, and this oxidation was the rate-limiting step in the binding process. Oxidative polymerization by laccase or peroxidaseleads to precursors of humic substances al so with other phenolic compounds $(9,26)$. Methylation of the hydroxy group reduced the binding of 8-OH-bentazon to humic substances substantially. Our results suggest that $8-\mathrm{OH}$ bentazon was dimerized by oxidativemicrobial enzymes such as laccase and that this dimer bound to clay-humic complexes. Also Phanerochaete chrysosporium which does not form laccase but lignin peroxidase or manganese peroxidase accelerated the binding of bentazon to soil humic substances, indicating that theoxidativeenzymes produced by thisfungus also produce reactiveoxidized bentazon derivatives. Whether the dimeric derivative is an obligate intermediate of $8-\mathrm{OH}$ bentazon binding or only a reactive side product is a matter that needs to be elucidated further.

Degradation of Bound Residues. The rate of mineralization of bound bentazon residues was assayed in an incubation experiment with humic material that was prepared by preincubation with $\mathrm{U}-{ }^{14} \mathrm{C}$-phenyl labeled bentazon, analogous to the experiment described in Figure 2. Nonbound parent compounds were removed by extraction with methanol. After 141 days of incubation, $9.3 \%$ of the bound labeled carbon was transformed to ${ }^{14} \mathrm{CO}_{2}$, equivalent to one-third of the mineralization rate observed with the free parent compound (Figure 6). The bound radioactivity was found in all humic fractions, i.e., fulvic acids, humic acids, and humins. A time-dependent shift of the bound residues from low- to high-molecular humic fractions ("aging") was observed by gradient gel electrophoresis (27).

As shown in our experiments, up to $9.3 \%(w / w)$ of the bound residues was mineralized in 141 days. This mineralization rate is similar to that reported earlier (4) and was also comparable to that published for bound residues formed from 2,4-dichlorophenol (28).

\section{Summary}

The results of our experiments could be summarized in a flow scheme illustrating the flux of bentazon and its metabolites through various pools in the soil (Figure 7): $12-$ $15 \%$ of added bentazon was mineralized immediately, 5\% methylated and afterward demethylated, and $65-85 \%$ was hydroxylated by microbial activity to 8-OH-bentazon. 8-OHBentazon could either bind directly to the humic matrix or could bedimerized by fungal or bacterial activity or bylaccase 


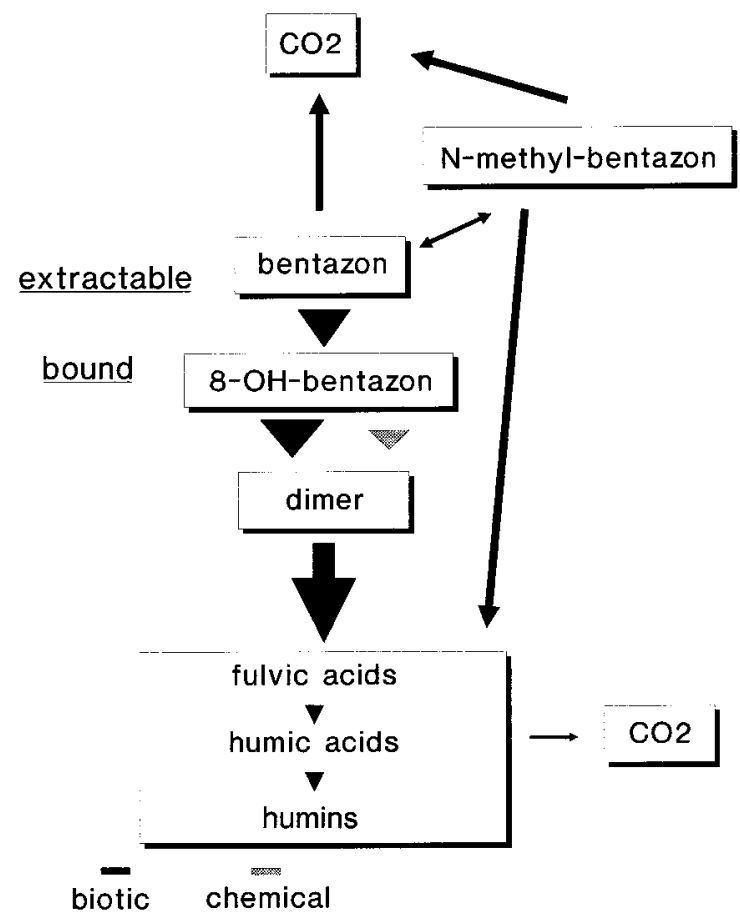

FIGURE 7. Proposed model of transformation of bentazon and its metabolites in soil. The width of the arrow $s$ indicates the relative quantitative importance of the respective reaction path.

action. This dimer binds covalently to humic substances through a nonbiotic, chemical reaction. The bound labeled residues in the humic substance behave in a similar manner as natural humic constituents do; within 141 days, 9.3\% of the bound residues was mineralized.

\section{Acknowledgments}

The authors want to thank BASF AG, Ludwigshafen, for financial and laboratory support.

\section{Literature Cited}

(1) Gaynor, J. D.; Hamill, A. S. Can. J. Plant Sci. 1983, 63, 10151022.

(2) Marsh, J. A. P.; Wingfield, G. I.; Davies, H. A.; Grossbard, E. Weed Res. 1978, 18, 293-300.

(3) Ross, L. J.; Powell, S.; Fleck, J. E.; Buechler, B. J. Environ. Qual. 1989, 18, 105-109.
(4) Lee, J. K.; Führ, F.; Mittelstaedt, W. Chemosphere 1988, 17, 441450.

(5) Müller, P. Phytopharmakologie, Verhalten und Wirkungsweise von Pflanzenschutzmitteln; Verlag Eugen Ulmer: Stuttgart, 1986.

(6) Rieck, C. E.; Wright, T. H.; Maksymowicz, W.; Thompson, L. Jr. Proc. N. Cent. Weed Control Conf. 1972, 27/50.

(7) Otto, S.; Beutel, P.; Drescher, N.; Huber R. IUPAC Adv. Pest. Sci. 1978, 551-556.

(8) Huber, R.; Otto, S. Rev. Environ. Contam. Toxicol. 1994, 137, $111-134$

(9) Bollag, J.-M.; Myers, C. J.; Minard, R. D. Sci. Total Environ. 1992 123/ 124, 205-217

(10) Bollag, J.-M.; Myers, C. J.; Pal, S.; Huang, P. M. In Environmental impact of soil component interaction; Huang P. M., Berthelin, J., Bollag, J.-M., McGill, W. B., Page, A. L. Eds.; CRC Press: Boca Raton, FL, 1995; pp 299-309.

(11) Abernathy, J. R.; Wax, L. M. Weed Sci. 1973, 21, 224-227.

(12) Kim, J.-E.; Wang, C.-J.; Bollag, J.-M. Biodegradation 1998, 8, 387-392.

(13) Martin, J. P.; Haider, K. Soil Sci. Soc. Am. J. 1980, 44, 983-988.

(14) Alef, K. Methodenhandbuch Bodenmikrobiologie; Ecomed: Landsberg, Germany, 1991; pp 158-160.

(15) Szabo, G.; Farkas, G.; Bulman, R. A. Chemosphere 1992, 24, $403-$ 412.

(16) Kirk, T. K.; Schultz, E.; Connors, W. J.; Lorenz, L. F.; Zeikus, J. G. Arch. Microbiol. 1978, 117, 277-285.

(17) Schnitzer, M.; Schuppli, P. Soil Sci. Soc. Am. J. 1989, 53, 1418 1424.

(18) Finger, W.; Post, B.; Klamberg, H. Z. Pflanzenernähr. Bodenk. 1990, 153, 305-312.

(19) Manilal, V. B.; Alexander, M. Appl. Microbiol. Biotechnol. 1991, 35, 401-405.

(20) Topp, E.; Hanson, R. S. Can. J. Soil Sci. 1990, 70, 83-91.

(21) Wagner, S. C.; Zablotowicz, R. M.; Gaston, L. A.; Locke, M. A.; Kinsella, J. J. Agric. Food Sci. 1996, 44, 1593-1598.

(22) Shindo, H.; Huang, P. M. Nature(London) 1982, 298, 363-365.

(23) Anderson, J. P. E.; Domsch, K. H. Can. J. Microbiol. 1975, 21 , $314-322$.

(24) Koenig, K.; Andreesen, J. R. Bioeng. 1992, 2, 78-92.

(25) Wiese, M.; Vargas, J. M. Pestic. Biochem. Physiol. 1973, 3, 214 222.

(26) Sjoblad, R. D.; Bollag, J.-M. In Soil Biochemistry; Paul, E. A. Ladd, J. N., Eds.; Marcel Dekker Inc.: New York; 1981; pp 113152.

(27) Knauber, W.-R.; Krotzky, A. J.; Schink, B. Soil Biol. Biochem. 1998, 30, 969-973.

(28) Bollag, J.-M. In Pesticide Transformation Products, fate and significance in the environment; Somasundaram, L., Coats, J. R., Eds.; ACS Symposium Series 459; American Chemical Society: Washington DC, 1991; pp 122-132.

Received for review April 14, 1999. Revised manuscript received November 19, 1999. Accepted November 23, 1999.

ES990426H 